\title{
PENGGUNAAN MEDIA PUZZLE GAMES UNTUK MENINGKATKAN AKTIFITAS BELAJAR PESERTA DIDIK DALAM POKOK BAHASAN IKATAN KIMIA DI SMA NEGERI 8 PEKANBARU
}

\author{
Faiza Ayesha $^{1}$, Jimmi Copriady $^{2} *$, Sulismayati $^{3}$, Basri Anshari $^{3}$ \\ ${ }^{1}$ Peserta SM-3T LPTK UNP \\ ${ }^{2}$ Prodi Pendidikan Kimia FKIP UR \\ ${ }^{3}$ SMAN 8 Pekanbaru \\ E-mail : jimmi.c@unri.ac.id
}

\begin{abstract}
This study is an action research (classroom action research) that uses two-cycle. The aim of this research is to improve the learning activities of students in chemical bonding topic in class X MIA 10 Senior High School (SMA) 8 Pekanbaru by using media Puzzle Games. Descriptive analysis is run for analyzing data. The instrument of this study using observation sheet activity. In the first cycle, the average percentage of students learning activity by $80 \%$ in both categories, a further meeting activity by $85 \%$ with very good category, the third meeting of $86.5 \%$ with very good category while the fourth meeting amoun ted to $89.40 \%$ with very good category. At the first meeting the activities of teachers percentage of $90.27 \%$ with a very good category, the second meeting amounted to $91.67 \%$ (excellent), the third meeting amounted to $93.05 \%$ (excellent), the fourth meeting amounted to $95.83 \%$ (excellent). The first cycle test results obtained an average of 84.05 while classical final test results of the second cycle of 95.83. Based on the analysis results there was an increase in the study of students from the first cycle to the second cycle. As for mastery learning of individual students, the first cycle refers to the Department of Education standards are $94.4 \%$ of students who completed school KKM standards while $88.8 \%$ of students who completed. In the second cycle by the Department of Education standards, completeness learners achieve $100 \%$ (complete), while for the standard 94.4\% KKM school (complete). Thus, the results of studying chemistry in subject of chemical bonding can be improved students activities and achievement by using instructional media puzzle games.
\end{abstract}

Keywords: Media of learning, Puzzle Games, learning activities

\begin{abstract}
Abstrak
Penelitian ini merupakan suatu penelitian tindakan kelas (classroom action research) yang menggunakan dua siklus dengan tujuan untuk meningkatkan aktivitas belajar peserta didik pada materi ikatan kimia di kelas X MIA 10 SMA NEGERI 8 PEKANBARU menggunakan media Puzzle Games. Analisis deskriptif dijalankan untuk menganalsis data hasil penelitian. Instrumen penelitian ini menggunakan lembar observasi aktivitas. Pada siklus pertama, persentase rata-rata aktivitas belajar peserta didik sebesar $80 \%$ dengan kategori baik, pertemuan selanjutnya aktivitas sebesar $85 \%$ dengan kategori sangat baik, pertemuan ketiga sebesar $86,5 \%$ dengan kategori sangat baik sedangkan pada pertemuan keempat sebesar $89,40 \%$ dengan kategori sangat baik. Pada pertemuan pertama persentase aktivitas guru sebesar 90,27\% dengan kategori sangat baik, pertemuan kedua sebesar 91,67\% (sangat baik), pertemuan ketiga sebesar 93,05\% (sangat baik), pertemuan keempat sebesar 95,83\% (sangat baik). Hasil tes siklus
\end{abstract}


pertama diperoleh rata-rata klasikal 84,05 sedangkan hasil tes akhir siklus kedua sebesar 95,83 . Berdasarkan hasil analisis terdapat peningkatan hasil belajar peserta didik dari siklus pertama ke siklus kedua. Adapun untuk ketuntasan belajar peserta didik individu, pada siklus pertama mengacu pada standart Depdikbud terdapat 94,4\% peserta didik yang tuntas sedangkan untuk standar KKM sekolah $88,8 \%$ peserta didik yang tuntas. Pada siklus kedua berdasarkan standar Depdikbud, ketuntasan peserta didik mencapai $100 \%$ (tuntas) sedangkan untuk standar KKM sekolah 94,4\% (tuntas). Dengan demikian, hasil belajar kimia pada pokok bahasan ikatan kimia dapat ditingkatkan dengan menggunakan media pembelajaran puzzle games pada peserta.

Kata Kunci: Media Pembelajaran, Puzzle Games, aktivitas belajar

\section{PENDAHULUAN}

Pembelajaran merupakan suatu tahap yang harus di tempuh peserta didik baik di sekolah maupun perguruan tinggi. Pembelajaran (instruction) merupakan suatu sistem yang bertujuan untuk membantu proses belajar siswa, yang berisi serangkaian pristiwa yang dirancang, disusun sedemikian rupa untuk mendukung dan mempengaruhi terjadinya proses belajar siswa yang bersifat internal (Ainurrahman, 2009). Menurut Hamalik (2005), belajar tidak cukup hanya mendengar dan melihat tetapi harus dengan melakukan aktivitas yang lain, diantaranya membaca, bertanya, menjawab, berpendapat, mengerjakan tugas, menggambar, diskusi, mengkomunikasikan, menyimpulkan dan memanfaatkan peralatan.

Proses pembelajaran dalam Kurikulum 2013 menuntut adanya partisipasi aktif dari seluruh peserta didik. Jadi kegiatan belajar berpusat pada peserta didik, guru sebagai motivator dan fasilitator supaya suasana proses pengajaran dan pembelajaran di kelas lebih hidup dan menyenangkan sehingga dapat menarik minat siswa untuk ikut terlibat dalam pembelajaran tersebut. Menurut Udin dkk (2005) pembelajaran adalah suatu sistem lingkungan belajar yang terdiri dari unsur-unsur seperti tujuan, bahan pelajaran, strategi, alat, siswa dan guru. Karena itu, dapat dikatakan bahwa pembelajaran pada hakekatnya merupakan suatu proses komunikasi antara guru yang bertindak sebagai komunikator dan siswa sebagai penerima pesan (Udin dkk, 2005).

Upaya memaksimalkan pencapaian hasil belajar dan aktivitas peserta didik, seorang guru seharusnya mampu memilih model, metode, media, yang sesuai dengan tujuan dan materi yang disamapaikan. Agar peserta didik dapat memahami apa yang telah di sampaikan dan tercapainya tujuan pembelajaran yang di tetapkan. Hasil belajar adalah pola-pola perebutan, nilai-nilai, pengetian-pengertian, sikap-sikap, apresiasi dan 
keterampilan (Suprijono, 2012). Sedangkan menurut Slameto (2010), hasil belajar dan proses belajar, kedua-duanya penting, di dalam belajar ini, terjadi proses berpikir.

Dalam proses pembelajaran, kehadiran media mempunyai arti penting karena dapat mengundang minat dan meningkatkan partisipasi peserta didik dalam proses pembelajaran. Media sendiri dibuat untuk mempermudah guru dalam menyampaikan teori. Mulyati dkk (2005) mengatakan bahwa penggunaan media dalam proses pembelajaran dapat membantu guru dalam mempermudah, menyederhanakan, dan mempercepat keberlangsungan proses pembelajaran, penyajian informasi secara utuh dan lengkap, serta membantu merancang lingkup materi pembelajaran secara sistematis sesuai dengan tingkat kemampuan dan alokasi waktu. Menurut Daryanto (2010), media pembelajaran adalah segala sesuatu yang dapat digunakan untuk menyalurkan pesan (materi pembelajaran), sehingga dapat merangsang perhatian, minat, pikiran, dan perasaan siswa dalam kegiatan belajar untuk mencapai tujuan pembelajaran. Dengan adanya media diharapkan lebih menarik minat peserta didik dalam mengikuti serta mencerna apa yang di sampaikan gurunya. Selain mempermudah guru, media sendiri dapat di modifikasi dengan berbagai macam jenisnya, contoh: media audio, media visual, media audio visual, multimedia, dan media yang dapat dimanipulasi. Diantara media pembelajaran yang dapat digunakan adalah media pembelajaran puzzle games.

Puzzle adalah permainan yang berupa teka-teki akan tetapi pada prinsipnya menekankan pada keserasian, keindahan, ketersalingan dan kelengkapan atau melengkapi yang kontruktif (Fauzan, 2007). Penggunaan media puzzle games merupakan salah satu media alternatif yang dapat digunakan untuk pembelajaran untuk materi ikatan kimia, karena mampu membuat suasana kelas menjadi menyenangkan. Media puzzle yang baik hendaknya mengembangkan daya imajinasi dan kreativitas berpikir anak. Media puzzle adalah media visual dua dimensi yang mempunyai kemampuan untuk menyampaikan informasi secara visual tentang segala sesuatu sebagai pindahan dari wujud yang sebenarnya (Wahyuni, 2010).

Menurut Yudha (2007) puzzle merupakan suatu gambar yang dapat dibagi menjadi potongan-potongan gambar dengan tujuan untuk mengasah daya pikir, melatih kesabaran, dan membiasakan kemampuan berbagi. Selain itu, media puzzle juga dapat disebut sebagai suatu permainan yang dapat mendidik karena dalam pelaksanaanya tidak hanya untuk bermain tetapi juga mengasah otak dan melatih antara kecepatan 
pikiran dan tangan. Menurut Nisak (2011), permainan ini mempunyai teknis sebagai berikut: 1) Guru menerangkan aturan permainan. Permainan ini dilakukan secara berkelompok. 2) Sebelum permainan dimulai dilakukan pembagian kelompok. Satu kelompok terdiri dari 5 anggota kelompok. 3) Siapkan puzzle dalam amplop untuk masing-masing kelompok. 4) Permainan ini dibatasi dengan waktu 15 menit. 5) Masingmasing kelompok berdiri melingkari meja dan didekat amplop puzzle yang telah dibagikan. 6) Masing- masing kelompok harus mengerjakan secara berkelompok, tidak boleh ada yang mengerjakan sendirian. 7) Guru memberikan umpan balik berupa pertanyaan-pertanyaan tentang gambar yang telah mereka rangkai.

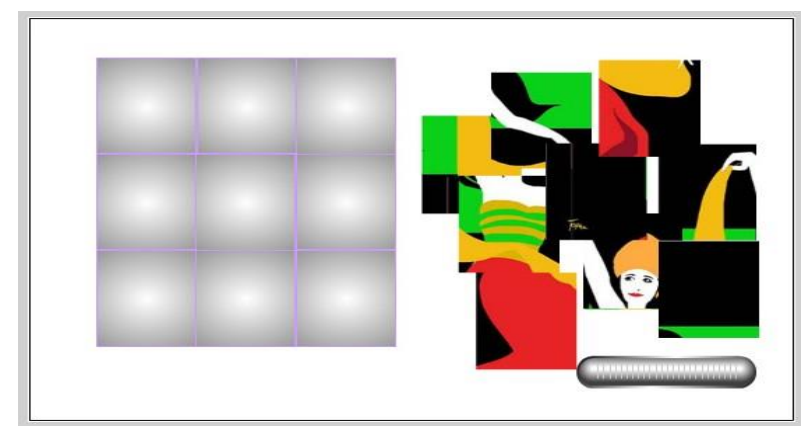

Gambar 1. Contoh papan puzzle dengan beberapa keping potongan gambar puzzle

(Sumber : Sutopo. H., 2009)

Menurut Al-Azizy (2010) manfaat bermain puzzle adalah a) mengasah otak, b) melatih koordinasi mata dan tangan, c) melatih nalar d) melatih kesabaran dan e) memberikan pengetahuan. Pengetahuan yang diperoleh dengan cara bermain biasanya lebih mengesankan dibanding dengan pengetahuan yang dihafalkan. Gambar yang terbentuk pada media puzzle diharapkan akan dapat membantu siswa dalam memahami materi, menjawab pertanyaan dari guru serta meningkatkan aktivitas dan kreatifitas siswa.

Berdasarkan hasil observasi dan wawancara dengan guru pamong terlihat masalah pada proses pembelajaran terutama dalam proses diskusi berlangsung apalagi kalau materi yang sedang didiskusikan adalah materi yang bersifat teori dan hafalan. Ketuntasan belajar peserta didik SMAN 8 Pekanbaru secara individu telah tercapai, namun ketuntasan secara klasikal masih dibawah $85 \%$. Peserta didik dikatakan tuntas belajar secara klasikal bila memperoleh persentase daya secara klasikal $\geq 85 \%$. Kemampuan peserta didik di SMAN 8 Pekanbaru pada umumnya menengah ke atas, sehingga mereka cepat jenuh dengan pembelajaran yang kurang menarik. Guru telah 
sering melakukan variasi dalam pembelajaran, namun masih terkendala pada materi ikatan kimia.

Berdasarkan uraian di atas, penulis tertarik untuk melakukan penelitian menggunakan media puzzle games dalam proses pembelajaran kimia dengan penelitian yang berjudul "Penggunaan Media Puzzle Games Untuk Meningkatkan Aktivitas Belajar Peserta Didik Dalam Pokok Bahasan Ikatan Kimia Pada Kelas X MIA 10 SMA Negeri 8 Pekanbaru".

\section{METODE PENELITIAN}

\section{Desain Penelitian}

Penelitian ini menggunakan metode Penelitian Tindakan kelas (Classroom Action Research). Peneliti menggunakan metode PTK karena metode ini memiliki peranan yang sangat penting dan strategis untuk meningkatkan mutu pembelajaran apabila diimplementasikan dengan baik dan benar. Diimplementasikan dengan benar artinya pihak terlibat dalam PTK yang dalam hal ini adalah guru mencoba dengan sadar mengembangkan kemampuan dalam mendeteksi dan memecahkan masalah-masalah yang terjadi dalam pembelajaran di kelas melalui tindakan bermakna yang diperhitungkan dapat memecahkan masalah atau memperbaiki situasi dan kemudian secara cermat mengamati pelaksanaannya untuk mengukur tingkat keberhasilannya.

Penelitian tindakan kelas ini sangat bermanfaat bagi guru untuk meningkatkan proses dan kualitas atau hasil pembelajaran di kelas. Dengan melaksanakan tahapantahapan PTK, guru dapat menemukan penyelesaian bagi masalah yang terjadi di kelasnya sendiri, dan bukan di kelas guru yang lain. Tentu saja dengan menerapkan barbagai ragam teori dan teknik pembelajaran yang relevan secara kreatif. Selain itu, peneliti praktis, PTK dilaksanakan bersamaan guru melaksanakan tugas utama yaitu mengajar di dalam kelas, tidak perlu harus meninggalkan siswa.

\section{Sampel, Waktu dan Tempat Penelitian}

Pada penelitian tindakan kelas ini, dilaksanakan di SMAN 8 Pekanbaru pada mata pelajaran kimia materi Ikatan Kimia. Subjek penelitian adalah siswa kelas X MIA 10 tahun pelajaran 2016-2017 yang berjumlah 36 orang. 
Penelitian tindakan kelas ini dilaksanakan di SMAN 8 Pekanbaru pada semester 1 tahun pelajaran 2016-2017 yaitu dari tanggal 19 Oktober s/d 9 November 2016 sesuai dengan kalender pendidikan atau kalender akademik sekolah serta Rencana Program Pembelajaran (RPP) yang telah guru/peneliti buat.

\section{Prosedur Siklus Penelitian}

Puzzle games berupa kartu-kartu yang berisi kata-kata mengenai materi ikatan kimia, dimana peserta didik akan menyusun kartu-kartu tersebut menjadi pasangan yang tepat. Peserta didik selain mendapat kesenangan juga mendapatkan pengetahuan dan pemahaman materi ikatan kimia, karena agar dapat menyusun kepingan puzzle tersebut dengan benar maka peserta didik harus mengerti dengan materi pembelajaran

Kegiatan penelitian tindakan kelas ini dirancang dan akan dilaksanakan dalam 2 (dua) siklus, yaitu siklus I dan siklus II. Pada siklus I dan siklus II terdiri atas perencanaan, pelaksanaan, pengamatan, dan refleksi. Pelaksanaan tiap siklus akan diambil satu kelas yang sama. Hal ini ditempuh untuk membandingkan dan menggambarkan proses pembelajaran pada tiap-tiap siklus. Sebagai langkah-langkah besar yang akan dilakukan adalah sebagai berikut:

\section{Siklus I}

a. Perencanaan

Pada kegiatan ini guru melakukan :

1) Melakukan observasi pada kelas yang menjadi objek penelitian.

2) Konsultasi dengan guru pamong.

3) Merencanakan pembelajaran dengan membuat Rencana Pelaksanaan Pembelajaran (RRP).

4) Menyiapkan LKPD (Lembar Kerja Peserta Didik) yang digunakan sebagai bahan diskusi siswa.

5) Menyiapkan media puzzle games.

6) Menyiapkan instrumen penelitian (lembar observasi, dan angket siswa)

b. Pelaksanaan

Kegiatan yang dilaksanakan pada tahap ini adalah melaksanakan rencana pembelajaran yang telah dibuat dengan tahapan sebagai berikut :

1) Menyiapkan kelas untuk belajar 
2) Menyampaikan apersepsi dan motivasi

3) Menyampaikan materi ikatan kimia dengan media power point

4) Peserta didik berdiskusi dalam kelompoknya menyelesaikan kegiatan yang ada di LKPD.

5) Peserta didik mempresentasikan hasil diskusi

6) Peserta didik menyimpulkan materi yang telah dipelajari

7) Peserta didik bermain puzzle games.

c. Pengamatan

Pada kegiatan ini, observer melakukan pengamatan dengan mencatat :

1) Aktivitas dan gaya guru dalam melaksanakan pembelajaran.

2) Aktivitas siswa selama proses pembelajaran berlangsung dan melakukan wawancara setelah pembelajaran selesai.

d. Refleksi

Pada kegiatan ini :

1) Guru dengan observer membahas tentang kelemahan atau kekurangan proses pembelajaran yang telah dilakukan.

2) Menganalisis data yang diperoleh untuk memperbaiki dan menyempurnakan tindakan pada siklus selanjutnya.

3) Menganalisis temuan saat melakukan pengamatan proses pembelajaran yang telah dilakukan, menganalisis kelemahan dan kelebihan dari proses pembelajaran yang berlangsung dan mempertimbangkan langkah selanjutnya pada siklus berikutnya.

Penelitian Tindakan Kelas ini berhasil apabila memenuhi beberapa syarat sebagai berikut.

a. Sebagian besar ( $80 \%$ dari peserta didik) sudah aktif dalam belajar.

b. Sebagian besar ( $80 \%$ dari peserta didik) sudah terpusat perhatiannya kepada guru dan sudah ada umpan balik terhadap pertanyaan guru.

c. Sebagian besar ( $80 \%$ dari peserta didik) sudah termotivasi dalam belajar.

d. Sebagian besar ( $80 \%$ dari peserta didik) sudah mencapai ketuntasan belajar.

\section{Siklus II}

Pada siklus II, peneliti berdiskusi dengan observer melakukan revisi proses pembelajaran, agar proses pembelajaran pada siklus II menjadi lebih baik. Siklus II ini 
dilaksanakan dengan mengikuti tahapan-tahapan seperti pada siklus I. Tapi, pada siklus II ini dilakukan perbaikan atau penyempurnaan terhadap pelaksanaan pembelajaran siklus I agar mencapai indikator keberhasilan yang telah ditetapkan.

Pada penelitian ini ada dua jenis data yaitu data kuantitatif dan kualitatif. Data kuantitatif didapatkan melalui tes hasil belajar yang dilakukan peserta didik. Sedangkan data kualitatif didapat melalui observasi aktivitas guru dan peserta didik.

\section{Analisis Data Penelitian}

Hasil belajar peserta didik dihitung dengan rumus ketuntasan belajar sebagai berikut:

Ketuntasan belajar peserta didik individu

$$
=\frac{\text { Skor yang didapat }}{\text { Skor maksimum }} \times 100 \%
$$

Ketuntasan belajar peserta didik klasikal

$$
=\frac{\text { Jumlah peserta didik yang tuntas individu }}{\text { Jumlah peserta didik }} \times 100 \%
$$

Ketuntasan indikator pencapaian kompetensi individu $=\frac{\text { Jumlah IPK yang tuntas }}{\text { Jumlah total IPK }} \times 100 \%$

Ketuntasan indikator pencapaian kompetensi secara klasikal $=\frac{\text { Jumlah peserta didik yang tuntas IPK }}{\text { Jumlah peserta didik }} \times 100 \%$

Keterangan:

Ketuntasan Individual : Jika ketuntasan siswa mencapai $>70 \%$

Ketuntasan Klasikal : Jika $>85 \%$ dari seluruh siswa mencapai ketuntasan $>70 \%$

Namun di SMA N 8 Pekanbaru, KKM pada mata pelajaran kimia ditetapkan adalah 80 . Jadi, ketuntasan individu peserta didik harus $\geq 80 \%$ agar bisa dikatakan tuntas. Aktivitas guru dapat dihitung dengan rumus:

$$
\text { Persentase }=\frac{\text { Skor total aktivitas yang dilakukan guru }}{\text { Skor maksimum }}
$$

Indikator keberhasilan pada penelitian ini adalah terjadi peningkatan aktivitas belajar peserta didik dari kondisi awal, setelah dilakukan pembelajaran dengan menggunakan media pembelajaran puzzle games. Adapun rincian keberhasilan penelitian ini adalah: 
1. Peningkatan aktivitas belajar peserta didik dinyatakan berhasil apabila secara ratarata aktivitas peserta didik mencapai $85 \%$ untuk ke 8 indikator.

2. Hasil belajar peserta didik mencapai ketuntasan belajar $85 \%$ peserta didik telah tuntas KKM yang telah ditentukan oleh sekolah mata pelajaran kimia dengan nilai 80.

\section{HASIL PENELITIAN}

\section{A. Siklus I}

Berdasarkan hasil pengamatan dan evaluasi selama siklus I, diperoleh data sebagai berikut :

\section{Aktivitas guru dan aktivitas peserta didik}

Pada pelaksanaan kegiatan pembelajaran siklus I pengamatan yang dilakukan ialah pengamatan terhadap aktivitas guru dan aktivitas peserta didik saat proses pembelajaran berlangsung dengan mengisi lembar observasi yang tersedia yang dilakukan oleh observer. Rata-rata dari aktivitas belajar peserta didik yang diperoleh pada pertemuan 1 adalah $80 \%$ sedangkan pada pertemuan 2 adalah $85 \%$ (Tabel 1)

Tabel 1 persentase aktivitas peserta didik siklus I

\begin{tabular}{ccc}
\hline No & Aktivitas Peserta didik & Persentase \\
\hline 1 & Pertemuan 1 & 80 \\
\hline 2 & Pertemuan 2 & 85
\end{tabular}

Sedangkan untuk kriteria aktivitas guru dapat dilihat pada tabel 2

Tabel 2 Persentase aktivitas guru pada siklus I

\begin{tabular}{ccc}
\hline No & Aktivitas Guru & Persentase \\
\hline 1 & Pertemuan 1 & 90 \\
\hline 2 & Pertemuan 2 & 91 \\
\hline
\end{tabular}

Dari data ketuntasan belajar peserta didik individu, diperoleh ketuntasan belajar peserta didik klasikal yang dapat dilihat pada tabel 3.

Tabel 3 Ketuntasan belajar peserta didik klasikal

\begin{tabular}{ccccc}
\hline No & Standar & \% Ketuntasan & Jumlah tuntas & Jumlah tidak tuntas \\
\hline 1 & Depdikbud & $94.4 \%$ & 34 & 2 \\
\hline 2 & KKM sekolah & $88,9 \%$ & 32 & 4 \\
\hline
\end{tabular}


Setelah dilakukan observasi terhadap aktivitas belajar peserta didik dalam proses pembelajaran, maka dilakukan refleksi. Refleksi bertujuan untuk mengidentifikasi halhal positif dan masalah-masalah yang muncul pada siklus pertama ini dan akan diperbaiki pada siklus kedua dengan memberikan perlakuan-perlakuan tertentu.

Adapun masalah-masalah yang teridentifikasi dalam pelaksanaan siklus pertama serta alternatif pemecahan masalah ini sebagai berikut :

1) Pada pertemuan 1 dan 2 saat berdiskusi kelompok, masih ada peserta didik yang tidak mau bekerja sama dan hanya mngharapkan jawaban dari teman sekelompoknya. Untuk pemecahan masalah ini guru diharapkan lebih memperhatikan, memotivasi serta membimbing peserta didik tersebut agar mau terlibat aktif dalam kelompoknya.

2) Saat presentasi kelompok, masih ada peserta didik yang acuh tak acuh terhadap teman yang tampil presentasi. Untuk pemecahan masalah ini, guru dapat meminta kelompok peserta didik yang acuh tak acuh untuk tampil presentasi pada kegiatan berikutnya.

3) Untuk media puzzle games ini masih terdapat kelemahan yaitu waktu permainan yang terlalu lama. Untuk pemecahan masalah ini guru dapat mengelola permainan ini dengan lebih baik lagi.

\section{B. Siklus II}

Pada pelaksanaan kegiatan pembelajaran siklus II pengamatan yang dilakukan ialah pengamatan terhadap aktivitas guru dan aktivitas peserta didik saat proses pembelajaran berlangsung dengan megisi lembar observasi yang tersedia yang dilakukan oleh observer. Rata-rata dari aktivitas belajar peserta didik yang diperoleh pada pertemuan 3 adalah 86,02\% sedangkan pada pertemuan 4 adalah 89,40\%. Kriteria aktivitas belajar peserta didik dapat dilihat pada tabel 4 .

Tabel.4 Persentase Aktivitas Peserta Didik Siklus II

\begin{tabular}{ccc}
\hline No & Aktivitas Peserta didik & Persentase \\
\hline 1 & Pertemuan 1 & 86,5 \\
\hline 2 & Pertemuan 2 & 89 \\
\hline
\end{tabular}

Sedangkan untuk kriteria aktivitas guru dapat dilihat pada tabel 5 
Tabel 5 Persentase aktivitas guru pada siklus II

\begin{tabular}{ccc}
\hline No & Aktivitas Guru & Persentase \\
\hline 1 & Pertemuan 3 & 93 \\
\hline 2 & Pertemuan 4 & 95 \\
\hline
\end{tabular}

\section{Ketuntasan Belajar}

Berdasarkan hasil tes siklus II diperoleh data ketuntasan sebagai berikut :

\begin{tabular}{ccccc}
\hline No & Standar & \% Ketuntasan & Jumlah tuntas & Jumlah tidak tuntas \\
\hline 1 & Depdikbud & 100 & 36 & 0 \\
\hline 2 & KKM sekolah & 94 & 34 & 2 \\
\hline
\end{tabular}

Adapun masalah-masalah yang teridentifikasi dalam pelaksanaan siklus pertama dan diperbaiki pada siklus kedua sebagai berikut :

1) Pada pertemuan 3 dan 4 saat berdiskusi kelompok peserta didik sudah bekerja sama dengan baik dalam kelompoknya untuk mengisi LKPD. Guru memotivasi serta membimbing peserta didik tersebut agar mau terlibat aktif dalm kelompoknya. Dibandingkan dengan siklus I peserta didik lebih bersemangat dalam berdiskusi kelompok.

2) Saat presentasi kelompok, peserta didik memperhatikan terhadap teman yang tampil presentasi dan memberikan respon atas apa yang telah dipresentasikan oleh temannya.

3) Pengelolaan waktu untuk media puzzle games ini sudah cukup baik.

Pada siklus II ini, hasilnya secara umum lebih baik dari siklus I dan sudah mencapai kriteria keberhasilan. Baik itu aktivitas guru, aktivitas peserta didik maupun hasil belajar.

\section{PEMBAHASAN}

Berdasarkan analisa data aktivitas belajar peserta didik menunjukkan bahwa aktivitas belajar peserta didik mengalami peningkatan dari pertemuan 1 sampai pertemuan 4. Pada pertemuan 1 persentase rata-rata aktivitas belajar peserta didik sebesar $80 \%$ dengan kategori baik, pertemuan 2 sebesar $85 \%$ dengan kategori sangat baik, pertemuan 3 sebesar 86,05 \% dengan kategori sangat baik sedangkan pada pertemuan 4 sebesar $89 \%$ dengan kategori sangat baik. Pada pertemuan 1 persentase aktivitas guru sebesar $90 \%$ dengan kategori sangat baik, pertemuan 2 sebesar $91 \%$ 
kategori sangat baik, pertemuan 3 sebesar 93\% kategori sangat baik, pertemuan 4 sebesar $95 \%$ kategori sangat baik.

Hasil tes siklus I diperoleh rata-rata klasikal 85 sedangkan hasil tes akhir siklus 2 sebesar 95,83. Adanya peningkatan hasil belajar peserta didik dari siklus 1 ke siklus 2 . Berdasarkan ketuntasan belajar peserta didik individu, pada siklus 1 untuk standar Depdikbud 94,4 \% peserta didik yang tuntas sedangkan untuk standar KKM sekolah $88,8 \%$ peserta didik yang tuntas. Pada siklus II untuk standar Depdikbud 100\% tuntas sedangkan untuk standar KKM sekolah 94,4 \% peserta didik yang tuntas.

Keaktivan peserta didik juga mengalami peningkatan dari pertemuan 1 ke pertemuan 4. Media puzzle games membuat pembelajaran menjadi menarik karena merupakan permainan dengan adu kecepatan dan ketepatan, sehingga peserta didik merasa semangat, terpacu untuk menang. Aktivitas peserta didik sangat baik. Apalagi dalam pembelajaran, guru juga menampilkan video film 2 dimensi mengenai Ikatan Kimia untuk memudahkan peserta didik memahami materi. Video ini diputar disetiap awal pembelajaran.

Pembelajaran menggunakan media puzzle games menarik minat peserta didik dalam belajar, sehingga meningkatkan rasa ingin tahu peserta didik dan membuat peserta didik banyak bertanya mengenai materi yang dipelajari. Hal ini juga bisa menghilangkan kejenuhan peserta didik dalam belajar. Selain itu, guru juga memanfaatkan media puzzle games untuk memperkaya materi bagi peserta didik karena disetiap kartu dalam permainan terdapat soal-soal yang dijawab oleh peserta didik.

Faktor keberhasilan peserta didik dalam belajar sangat tergantung kepada keaktivan siswa itu sendiri sebagai subjek belajar (Sardiman, 2006). Peningkatan aktivitas peserta didik dalam pembelajaran mempengaruhi ketuntasan belajar peserta didik. Ketuntasan hasil belajar peserta didik juga mengalami peningkatan. Setelah menggunakan media pembelajaran puzzle games sebagai upaya guru untuk meningkatkan hasil belajar peserta didik, maka didapatkan ketuntasan klasikal sebesar $100 \%$. Artinya semua peserta didik di kelas X MIA 10 telah tuntas secara klasikal baik dengan standar Depdikbud ataupun KKM sekolah.

Ketuntasan indikator pencapaian kompetensi juga sudah sangat baik, namun masih ada IPK 1 yang masih mancapai persentase $71 \%$ dan IPK 3 yang masih $61 \%$. Persentase ketuntasan yang diharapkan adalah 85\%. Namun jika dilihat dari Standar 
Depdikbud, ketuntasan IPK keseluruhan telah mencapai $100 \%$ dari seluruh peserta didik, artinya telah mencapai kriteria yang diharapkan.

Jadi, dari hasil penelitian dan pembahasan seperti yang telah diuraikan di atas dapat menjelaskan bahwa hipotesis peneliti yang berbunyi "Dengan penggunaan media puzzle games dapat meningkatkan aktivitas belajar peserta didik pada pembelajaran Ikatan Kimia di Kelas X MIA 10 SMA Negeri 8 Pekanbaru “diterima”.

\section{KESIMPULAN}

Berdasarkan analisa hasil pengolahan data dan pembahasan yang telah diuraikan sebelumnya, maka dapat disimpulkan bahwa pembelajaran kimia dengan menggunakan media puzzle games pada materi ikatan kimia dapat membantu meningkatkan aktivitas belajar peserta didik. Pada pertemuan 1 persentase rata-rata aktivitas belajar peserta didik sebesar $80 \%$ dengan kategori baik, pertemuan 2 sebesar $85 \%$ dengan kategori sangat baik, pertemuan 3 sebesar $86,5 \%$ dengan kategori sangat baik sedangkan pada pertemuan 4 sebesar $89 \%$ dengan kategori sangat baik. Ketuntasan hasil belajar untuk standar Depdikbud, semua peserta didik telah mencapai ketuntasan, namun untuk standar KKM sekolah 94,44 \% yang telah mencapai ketuntasan.

\section{SARAN}

Dari hasil penelitian, maka penulis ingin menyumbangkan beberapa saran, yaitu :

a. Guru dapat menggunakan media pembelajaran puzzle games untuk materi iktan kimia.

b. Guru hendaknya membuat tampilan media puzzle games dengan tampilan yang lebih menarik agar peserta didik lebih termotivasi untuk belajar.

c. Guru hendaknya mengelola waktu dengan baik dalam puzzle games ini agar pembelajaran menjadi efektif dan efisien.

\section{DAFTAR PUSTAKA}

Ainurrahman. 2009. Belajar dan Pembelajaran. Bandung: Alfabeta.

Al-Azizy, A Suciaty. 2010. Ragam Latihan Khusus Asah Otak Anak Plus Melejitkan Daya Ingatannya. Diva Press : Jogjakarta.

Daryanto, 2010. Media Pembelajaran Peranannya Sangat Penting Dalam Mencapai Tujuain Pembelajaran, Yogyakarta: Gava Media. 
Fauzan, M. 2007. Permainan Edukatif dan Alat Permainan Edukatif Bagi PAUD. Bandung: Bumi Siliwangi.

Hamalik, Oemar. 2007. Proses Belajar Mengajar. Jakarta : Bumi Aksara

M, Fauzan. 2007. Permainan Edukatif dan Alat Permainan Edukatif bagi PAUD. Bandung:Bumi Siliwangi.

Mulyati Arifin, dkk.2005. Strategi Belajar Mengajar Kimia. Malang : UM Press.

Nisak, Raisatun. 2011. Lebih Dari 50 Game Kreatif Untuk Aktivitas Belajar Mengajar. Jogjakarta: Diva Press.

Sardiman. 2006. Interaksi dan Motivasi Belajar Mengajar. Jakarta: PT Raja Grafindo Persada

Slameto. 2012. Belajar dan Faktor-Faktor yang mempengaruhi. Jakarta: Rineka Cipta

Suprijono. Agus. 2012. Cooperatif Learning Teori Dan Aplikasi Palkem. Yogyakarta: Pustaka Belajar.

Sutopo. H., 2009. Pengembangan model pembelajaran pembuatan aplikasi multimedia khususnya puzzle game pada mata kuliah multimedia. Disertasi Universitas Negeri jakarta.

Udin S. Winataputra, dkk. 2005. Strategi Belajar Mengajar. Jakarta: Universitas Terbuka.

Wahyuni, Nanik. 2010. Pemanfaatan Media Puzzle Metamorfosis Dalam Pembelajaran SAINS Untuk Meningkatkan Hasil Belajar Siswa Kelas II SDN Sawunggaling I/328 Surabaya. Jurnal Teknologi Pendidikan, (Online). Vol 10, No. 2, http://www. tp.ac.id, diakses 18 Februari 2017)

Yudha, P. 2007. “ Pengaruh Penerapan Corporate Governance Terhadap Kinerja Keuangan Perusahaan". Skripsi Mahasiswa, Universitas Islam Indonesia Yogyakarta. 